\title{
Towards a Pragmatic Perspective on Business Innovation in Western Balkan Countries: The Case of Albania
}

\author{
Peter Nientied $^{1} \&$ Elona Karafili ${ }^{2}$ \\ ${ }^{1}$ NCOI University, Hilversum, the Netherlands, and Polis University, Tirana, Albania \\ ${ }^{2}$ Polis University, Tirana, Albania \\ Correspondence: Elona Karafili, Polis University, Tirana, Albania. Tel: 355-4240-7420. E-mail: \\ elona_karafili@universitetipolis.edu.al \\ Received: January 20, 2016 \\ doi:10.5539/ijbm.v11n3p193 \\ Accepted: February 3, 2016 \\ Online Published: February 25, 2016
}

\begin{abstract}
Recent reports and articles on innovation and innovation management in the Western Balkan countries conclude that innovation is quite limited. It is suggested that the development of a national innovation system is needed to increase innovation capacity and innovation outcomes. However, this is a conventional perspective which has so far not worked. In this article we explore Albania as a Western Balkan case. The aim of the article is to learn from a better contextualization of innovation, by taking into account the specific conditions of the Western Balkan countries and Albania in particular. Results of empirical research confirm that the innovation capacity of Albanian firms is rather minimal indeed. They also provide insights that lead to an alternative perspective of fostering business innovation in Albania; not a focus on building a national innovation system but on a pragmatic 'everyday innovation' approach. This perspective should be relevant for other Western Balkan countries too.
\end{abstract}

Keywords: innovation, business development, innovation policy, Western Balkan, Albania

\section{Introduction}

Innovation means the successful exploitation of new ideas, a process of turning ideas into reality and capturing value from them (Tidd \& Bessant, 2013; Davila et al., 2013). Newness of services, products, processes and business models, is defined at the organizational level. An idea may not be new to the world, but is new for an organization and its context. Innovation in lower mid-income countries like the Western Balkan countries (Albania, Bosnia and Herzegovina, Macedonia, Serbia, Croatia, Kosovo and Montenegro) is different from the innovation processes in richer countries. Technological capabilities and higher education systems are not well developed in the Western Balkan; and Western Balkan countries do not have a strong tradition of international trade and exchange (drivers for innovation) and have small domestic markets.

In the Western Balkan, the need for more innovation is stressed by scholars, policy makers and international agencies. At the regional and national levels, competitiveness criteria lag behind, few new products are developed and technical systems and new service models are transferred from other countries. During the last few years, a number of reports and articles have been published on innovation in the Western Balkan. Most of them focus on innovation in the national economy, on the obstacles to innovation, the need for more R\&D, et cetera. While we share the concerns put forward, we note that the current perspective is conventional; they focus on national level innovation management and on international benchmarks that take the development of advanced economies as a standard.

In this article Albania is our case study of the Western Balkan. The Albanian situation is studied and a critical view is taken of the conventional view that suggests to build up a national innovation system along Western European lines with a leading role for the government. Despite plans and policies proposed by the public sector, the results on the ground are far from convincing, as we will show. It is therefore timely to ask the question whether pursuing actions to build a national innovation system is the right thing to do, and whether theory behind national innovation systems fits the Western Balkan context. For practice this study is also relevant: the voices of entrepreneurs and managers are not often heart, and entrepreneurs are the actors that have to manage innovation in their organizations.

The flow of the article is as follows. First a number of recent reports and articles on innovation in Albania is 
reviewed. Then innovation in Albania will be contextualized from three angles: - Albania's development in recent history, - the limited push to innovate, and - the government's role in innovation. Results of empirical work (questionnaire survey, interviews with Albanian entrepreneurs and managers) show that innovation is at an early stage indeed and give a picture of innovation in the real world. After the analysis of documents and empirical research, an alternative perspective of fostering innovation is presented.

\subsection{Research Methodology}

Desk research, a literature review, semi-structured interviews, and a limited amount of questionnaire based interviews were the basis for this study. The aim of the survey was exploratory rather than generating data for empirical evidence based on a hypothesis. Over the last two years we did 15 semi-structured interviews with managers of organizations, including organizations acknowledged of being fore-runners in innovation. We asked post graduate executive MBA students to gather information through a questionnaire based interview. They took interviews in 29 organizations. An advantage of administering a survey through MBA students was that the response was very good because it was based on personal references. The questionnaire was built on Tidd and Bessant's (2013) model of innovation management and contains 25 statements on the organization's views of innovation management, innovation strategy, and relations with suppliers, clients and R\&D institutions. The questionnaire also contains a short descriptive part for data on the companies and their most important innovations of the last 3 years. A limitation of the survey is that it has an unknown bias in the type of organizations. Compared to all Albanian companies, the selection $(29+15$ organizations $)$ contains more international companies and bigger companies. These companies can be is expected to be more concerned with innovation (but also this selection with an expected positive bias to innovation, shows limited results). There were no companies from the agricultural and mining sectors. Most of the organizations have their offices in the capital and the central region of Albania - the most affluent part of the country.

\section{Albania's Innovation Gap}

Albania is in many aspects behind in the field of innovation. Private companies' technological capacity to upgrade by absorbing existing advanced technologies is weak, Albania scores low on patents, it has witnessed a substantial brain drain and it has low R\&D and investments (WEF, 2015; World Bank, 2011; World Bank, 2013; Cvetanovic et al., 2014). Indeed, Albania is not at all like some of the OECD and Asian countries that are known for their innovative industries and strong R\&D sectors. Gross expenditure on R\&D in Albania in 2008 was about 0.15 percent of GDP, funded almost exclusively by the public sector and by foreign sources. The research output was quite modest (Republic of Albania, 2009). Albania had only 245 researchers per million of population representing less than 10 percent of the EU average of 3,166 researchers per million of population (World Bank, 2013). Innovative performance, in terms of patents and citations, lags significantly behind EU averages, while availability of adequate ICT infrastructures is also a serious problem. There is a general legacy of unfinished reforms in the area of research, development and innovation. This area has suffered from neglect, as policies instead have focused more broadly on post-war and, more recently, post-financial and economic crisis restructuring. Only recently have governments in the Western Balkan made real efforts to formulate and implement strategies on R\&D and science and technology (World Bank, 2011; Marinkovic \& Dall, 2014). 1.3 percent of Albanian manufacturing exports are high-tech exports. This is significantly less than the exports in developing Sub-Saharan Africa countries (5.3 percent). The comparison with the OECD (19 percent), Euro area (16 percent) and developing upper middle-income countries (21.4 percent) is even more revealing (Redek, 2012, p. 99). Nazarani et al. (2011, p. 22) state: "Albania's most important exports are clothing, footwear and leather and agro-food products which have fairly high levels of foreign investment; however these branches of the private sector tend to have a low level of innovation and technology."

In the 2015-2016 WEF Competitiveness Ranking of 140 countries, Albania ranked no. 118 on the pillar 'Innovation' (WEF, 2015). In the Global Innovation Index 2015, Albania is characterized as an underperformer (WEF, 2014), and as a 'beginner' in the field of research based innovation (Švarc, 2012). The Global Competitiveness Report positions Albania - together with other Western Balkan countries - in the category of efficiency driven economies (stage 2). Applying the model of World Economic Forum, Feimi and Kume (2014, p. 243) recently studied the innovation in Albania with a focus on financial and insurance companies. For the country as a whole, they confirm that Albania is an efficiency-driven economy characterized by 'efficiency enhancers' such as higher education and training, efficient markets, labour market efficiency, financial market development, technological development and market size.

In short, from the literature it can be concluded that innovation in Albania is limited and that the innovation climate is not very favorable. From a perspective of an innovation capacity gap (between EU countries and the 
Western Balkan-and especially Albania), the differences are substantial indeed (cf. Švarc, 2012). How can we look at this gap? Should Albania follow the path of pursuing national innovation systems like richer EU countries? Is policy applied in economically developed countries, also relevant for a Western Balkan country like Albania that follows a quite different path of economic development? On innovation in emerging CEE economies, UNECE (2012, vii) suggests "Innovation potential is influenced by the scope of R\&D, which determines the stock of inventions and innovations to be commercialized; the quantity and quality of human resources available for $\mathrm{R} \& \mathrm{D}$, which depend on the number of universities and research institutions, and quality of education; regulatory and institutional environment conducive to innovation, including stable property rights; independence of the judiciary; transparent and simple rules, and low costs governing the registration and operation of enterprises; and the wide use of information and communication technologies. These factors influence the business climate in which the innovation-based enterprises operate, and thus determine the demand for innovation."

Albania is behind in international benchmarks on national innovation indicators but the relevance of such factors and their corresponding indicators can be questioned, as Kozlowski (2015) does. The indicators are from a technical point of view, supposed to be an accurate reflection of the phenomenon and mainly used for statistics. For example, for Albania it can be calculated how much government funds go to R\&D in universities, but what does it mean? What results are achieved? Kravtsova and Radosevic (2011) suggest that innovation systems (R\&D, educational systems) in Eastern Europe are inefficient; they have lower levels of productivity than might be expected given their research and development $(R \& D)$, innovation and production capabilities. The quality of the indicators can be questioned. Another point is whether there is any insight into the innovation demands for R\&D from the business sector in Albania? We claim that this does not exist, and that a 'stock of innovations'is an misconception. And another point concerns patents. Albania scores low on patents. In technical fields patents are important, but to what extent are patents relevant for a country that identified agriculture and tourism as two priority sectors for economic development?

Švarc (2012) made a comparative analysis of Western Balkan national innovation systems, and concludes that all Western Balkan countries (with the exception of Kosovo) have strategic documents in place related to research policies. The main difficulties however are related to a) the large number of strategic documents in different areas with a low-level of implementation; and b) 'Europeanisation' of innovation and research policies far away from the local problems and circumstances, i.e. strategic documents present only a copy of European schemes and approaches while lacking down-to-earth analysis of national capacities. The UNECE notion of 'the stock of inventions and innovations', and the 'volume of R\&D needed', signifies a rather conventional and mechanical ways of looking at innovation, assuming that Western European models will also work for Western Balkan countries.

On the role of government, UNECE (2012) gives directions on strengthening a national innovation system. This can be questioned, from various angles. Archibugi et al. (2009) state that it cannot be expected that the same causal relationships between technology and growth (that underlie the prevalent innovation management thinking) to have an identical impact on countries and regions that differ a lot in their dimensions, income, infrastructure and human resources. Sloan (2001), a European Commission researcher, asks a series of questions about the linkages between policy and innovation measurement, suggesting that causality cannot be confirmed. Most of Sloan's questions have, 15 years later, not been answered as yet for developed EU economies, let alone for lower mid-income countries like the Western Balkan countries.

Government does have a task in fostering innovation, especially in creating a positive business environment. But before starting to govern innovation, the government may ask itself what a positive business environment entails. Mehmeti (2014) concludes in her study that many reforms are needed by the Albanian government to improve the business climate. This is also the conclusion of tIMF (2015). IFAA (2015) discusses from the perspective of larger enterprises, serious flaws in the business climate. Xheneti and Bartlett (2012) carried out a study of 103 Albanian small and medium enterprises, asking them about institutional constraints. Their study shows that unfair competition, tax regulations, corruption and inadequate supply of infrastructure were the biggest hurdles for enterprises. The Albanian government is not very efficient, not innovative as an organization, and acknowledges that it has a problem with tackling corruption.

A closer look is taken now at the Albanian context to better understand the situation.

\section{Contextualizing Innovation in Albania}

Many factors can be identified that help to explain the limited innovation capacity at the level of the national economy. We cluster those under three headings. 


\section{i) Albania is a small, formerly isolated country, still catching up}

Albania has come from very far. In 1991 it changed its political economy from a closed communist system into an open economy. Since 1991, a lot of change has taken place, in all fields: political, social, economic, cultural. Despite various crises in the Albanian transition period, and despite the late transition to a market economy and under unfavorable conditions due to the country's dogmatic heritage (Redek et al., 2012; Prašnikar et al., 2013), Albania has witnessed a good economic performance - annual growth rates of $6 \%$ or more were no exception up to 2008. The private sector has shown great flexibility throughout the transition period - and learned to survive despite crises and a changeable government (Xheneti \& Bartlett, 2012). This has perhaps contributed to the short term time horizon of many entrepreneurs - an understandable business strategy which is not supportive however for developing an innovative climate. The construction sector was a lead sector and the country benefitted from a substantial amount of remittances.

With its 3.2 million inhabitants, Albania's size is modest. The current GDP per annum is about US\$ 4000 per capita. Agriculture accounted for 20.8 percent of GDP in 2009 and today agriculture is still dominated by small family owned operations that employ almost half of the labor force. Since 2008 the economic growth has been very modest due the global economic slowdown. The housing market has reached a sort of saturation point, hence the construction sector turned into crisis. Due to weakening links to the home country and especially due to the economic and financial situation in Western Europe, remittances from Albanian emigrants (mainly settled in Italy and Greece) have significantly decreased.

The Albanian economy has focused on getting basics in place - like the quality of higher education and training, financial market development, modernization of government, and other institutional issues. Much has been achieved, and much remains to be done (IMF, 2015). From the viewpoint of recent history since 1991, it is understandable that innovation related topics did not receive much attention: the economy grew in a dynamic way with strong ups and downs. Politicians have been very busy with organizing basics, managing donors, the always difficult Balkan situations and with their own national and local political interests and struggles.

\section{ii) The push to innovate has been limited}

After the closed, communist period came to an end in 1991, an entrepreneurial culture has developed in Albania. Sometimes this entrepreneurial culture conflicted vis-à-vis the law and vis-à-vis government frameworks - there is corruption and a lot of bureaucracy in the country. However, through entrepreneurs, the state and international agencies, the economy has grown substantially (IMF, 2015).

Albania has never been much into international competition, let alone global competition. It has limited exports, and receives small amounts of foreign investments in the productive economy. Prašnikar et al. (2012) analyze the domestic nature of competition of Albanian firms as a major factor; due to the lack of competition, one of the major innovation drivers was non-existent. Given that the majority of sales are conducted in the domestic market, the nature of competition is largely determined by the characteristics of domestic competition.

The limited capacity and propensity of entrepreneurs to innovate can be witnessed in the common copy-paste behavior in the service sector. Every visitor to the country is struck by the huge number of petrol pumps, bars, restaurants, construction companies, and so on, that are doing the same thing. It is possible, but data are not known, that black money plays a role in this type of investments. The point is the past and current preference to invest in the basics of the economy and in opportunities that are easily understandable.

Until recently, there was not a strong push to work very hard on innovation, not for firms and not for the government. Albania has worked hard to catch up and getting basics in place. The situation has changed since economic growth slowed down after 2008. Remittances have decreased and the government's debt ratio has reached a maximum. Now Albania will have to enter highly competitive international markets (agriculture, tourism). This should be a driver for innovation if Albanian firms want to survive.

\section{iii) The role of the government}

The role of the government has been limited so far in the field of innovation. To an extent this is understandable; after 1991 much attention has gone into defining what Albania is and into setting up institutions. Bahiti and Shahini (2010) conclude in their study on Albanian innovation and technology policy that "Albania has made significant progress in transition reforms in recent years but significant challenges remain. Business environment suffers from a high level of corruption, serious shortcomings in the judiciary, and very weak institutional and law enforcement capacity." (2010, 2002). Albania is now an aspiring candidate for EU and adopts EU regulatory frameworks. Institutions for the governance of innovation have been established - in 2010 the Agency for Research, Technology and Innovation (ARTI) was started, as a public, legal institution under the competences of 
the Council of Ministers (WBC-INCO.NET, 2011, Narazani et al., 2011) as well as Albanian Investment Development Agency. In 2013 a Ministry of Innovation and Public Administration was established. A question is what the government has achieved so far in the field of innovation; a self-reflection of the government of its policies and achievements so far, would be helpful.

\section{Indications from Practice}

As explained in the note on Research Methodology in the introduction, we collected a) in 2015 information with questionnaire based interview ( $\mathrm{n}=29)$, and $\mathrm{b})$ in 2014-2015 we interviewed managers of organizations $(\mathrm{n}=15)$, including organizations acknowledged to be fore-runners in innovation. All respondents were senior managers or owners of the company. Some characteristics of the organizations are in Table 1.

Table 1. Characteristics of all organizations $(n=44)$

\begin{tabular}{lll}
\hline Item & & $\%$ \\
\hline Sector & Service & $59 \%$ \\
& Production / construction & $30 \%$ \\
& Public sector / NGO's & $11 \%$ \\
\multirow{2}{*}{ Type } & National & $62 \%$ \\
& HQ abroad & $38 \%$ \\
Size & $>250$ employees & $72 \%$ \\
& 250 employees and less & $28 \%$ \\
\hline
\end{tabular}

$\mathrm{NGO}=$ nongovernmental organization, $\mathrm{HQ}=$ head quarters.

\section{a) Questionnaire based survey}

In the questionnaire based interviews, respondents were asked to mention their most significant recent innovation. The variety was - understandably - substantial. The most frequently mentioned examples refer to: new technology and materials (especially for production / construction companies); - new IT (4G / new transmission platforms, etc. especially for IT and telecom industries), - digitalization of services (e-banking, online payments, etc.).

From a comparison between national and international companies, and between smaller and larger companies, a clear picture emerges. In short: bigger and international often means more innovation, smaller and national means limited innovation. Companies working in telecommunication, banking and logistics sectors, as well as the services sector reported more innovation than others, albeit that many innovations are transferred from the headquarters abroad.

The organizations in the survey have a strong awareness of the competition. Companies do compare themselves with other firms in a systematic manner, but the nature of competition is mostly domestic. This also holds for international firms, since most of the Albanian companies are local representatives that are supposed to work for the Albanian market only.

Regarding strategy and leadership, the answers show that only few the 29 organizations have a strategy for innovation, and responsibilities for innovation are unclear. Albanian companies that are part of modern international organizations (such as DHL, Vodafone, Raifeissen Bank, etc.) generally implement an innovation strategy or plan that has been developed by the headquarters of their organization. International companies have global innovation strategies, and the task for the Albanian branches is to implement the strategy made elsewhere. This implies that innovation and innovation management as a skill and a management practice are not locally developed.

With regards to the topics of innovation climate within the organization, the lowest scores concern the openness of the companies and their ability / willingness to cooperate. The majority of the 29 organizations visited tends to operate isolated and do not really engage in partnerships with universities, research centers or other firms. This confirms a common feature of post-communist societies: a rather high mistrust among the actors.

\section{b) Interviews}

During 2014-5, we have also carried out 15 interviews, based on an item list, with representatives from not so innovative firms (footwear, textile, banking, food processing, construction and materials, etc.) and with representatives from innovative organizations like Digitalb and Polis University (Nientied, 2015). 
When asked about the major factors that were considered to be hurdles for more innovation, the following answers preponderated.

- Human resources: the brain drain has been a problem and education for required expertise in the fields is quite poor, implying high training and capacity building costs. For IT companies it is difficult to find technical staff, universities find it hard in a number of fields to find good $\mathrm{PhD}$ researchers and teaching staff.

- Government functioning is often seen as a problem. A quote from a Digitalb manager was "Government could have done much more with regards to infrastructure and education, but that aside, we prefer the government to do nothing, just let us do our job. The only expectation is that the government exercises its regulatory function and guarantees fair competition and that everybody respects the law."

- Collaboration between organizations is not common; everybody waits for others to take initiatives. Trust in other companies is quite low.

- Within organizations innovation is often considered to be an exclusive task of the top management. The employees are not supposed to come forward with innovative ideas.

We also interviewed start-up companies about their business development. Main points from these interviews are:

- The administrative burden for start-ups is high. Registering a firm is not difficult, but taxes, all sorts of procedures and bookkeeping is.

- It is difficult to work with government offices if one has no close friends in government or one is not willing to make a payoff. There is a lot of personal politics involved unfortunately.

- Until recently, there was no start-up culture in Albania. The first actions in the form of a start-up center (with support from USAID and UNDP) and relevant meetings are being undertaken now.

c) Analysis

Reflecting on the questionnaire survey work and the interviews, a few points emerge. Firstly, the concept of innovation is not well understood in most organizations. Managers have heart the term, but they have little awareness of its meaning. For many, any type of improvement is considered to be an innovation. For others, innovation is linked to IT, technology and product development. The subject of innovation is hardly taught in the Albanian educational systems and not a popular topic in business magazines. What innovation means for government is not very clear. The strategy on science, technology and innovation (period $2009-2015$ ) resulted in the establishment of institutions like ARTI (Agency for Research Technology and Innovation) and AIDA (Albanian Investment Development Agency). The amount of activities they undertake in the field of innovation is limited (see for example ARTI, 2014). In 2015, a Digital Agenda 2015-2020 was written, with positive ambitions.

A second point is that many innovations are transferred from abroad to Albania. The advantage is that this signifies a lower cost option (cf. Zavalani et al., 2015). Taken together with the mind-set of domestic competition, a drawback is that the priority for organizations is on the implementation of what has been developed abroad. Themes such as working on new business models, moving up the value chains, increase international business, searching for open innovation, fostering creativity in the company, are abracadabra in most organizations.

A third point is that almost none of the respondents take the innovation policy efforts of the government very seriously. It is true, respondents say, that the government has identified six economic sectors that are considered as strategic development priority (energy, mining, transportation, agriculture, tourism, technology and development), but what does this mean in the real world? Respondents find the Ministry of Innovation and Public Administration to be an odd combination. One respondent said: "Public administration is the opposite of innovation, innovation should be linked to economic development." Another respondent said: "We see meetings of people in and around the public sector in conference halls discussing small new things - we don't see much genuine promotion of innovation." Existing small government activities (such as the triple helix innovation competition, in collaboration with OECD and EU) were not known to the respondents. And after explanation such small activities were not considered to be attractive - it was expected that much bureaucracy is involved and the rewards are low.

\section{A Pragmatic Approach to Innovation}

Our empirical work has been somewhat limited, but, together with the extensive literature search, it was adequate for our purpose. Saturation of information has been achieved; more interviews and more questionnaires will not give much new information - just more confirmation that innovation is limited. More important is the 
question how businesses can be helped to foster creativity and produce innovation results, what the government should and should not do to stimulate innovation, and how business institutions can support innovation.

Based on our literature review and empirical work, we conclude that a policy focus on building a national innovation system is not very useful. It is an unsure, long term development that cannot be well governed. It results in policy documents that are not implemented, and are copies of what Western European countries have formulated (cf. Švarc, 2012). Instead, we favor an approach that we label 'everyday innovation', a term coined by NESTA (Patterson et al., 2009). This approach focuses on practice, on fostering creativity and innovation in companies in everyday life, as a regular element of business rather than a strategic specialty. For the Albanian case, we submit a few pointers for a discussion of this approach.

A first pointer is that it makes a lot of sense to start from the real world. More relevant than following the classical path of national innovation system development, are the experiences of mid-income countries (cf. OECD, 2015). In the current open global economy, the issue for Albania's innovation would be to find niches based on own resources and competencies. Applying a resource based approach means looking in a pragmatic, creative way at innovation. The starting point is the community of entrepreneurs, supported by business and research institutions, and government in a role of creating a proper business environment. A resource based approach also implies more focus on service innovation, process and management innovation and import of high tech solutions. Product and technical innovation thinking may be applicable to energy, engineering and manufacturing, but these sectors are small - and are likely to import innovative solutions, as they have done so far. Service innovation (e.g. for tourism), process innovation (e.g. agricultural supply chains) and management innovation (e.g. making organizations more innovation minded), will deliver smaller, but steadier and faster results that impact the economy and its small and medium enterprises. It will be an incremental way to develop innovation capabilities.

A second pointer concerns the link between innovation and entrepreneurship. Current policy approaches look at institutional infrastructure for innovation - long term and nation-wide. Where are the entrepreneurs in this perspective? Entrepreneurs understand running an enterprise better than abstract notions of innovation systems. It has to be clarified through in-depth studies, what hampers firms from more innovation practices, how they look at competition, and what blocks companies to expand their horizons and go international. This information will serve as a basis for business institutions to promote innovation awareness. The life cycle approach to fostering innovation-driven entrepreneurship 'Stand up - start up - scale up' (WEF, 2014) can be useful. Stand up implies strengthening entrepreneurship in the curriculum of education institutes, a task for education. It means giving opportunities to people to express their interest (such actions are undertaken at a small scale in Albania). Start-up implies giving limited support to wannabee entrepreneurs, preferably from and through other entrepreneurs. There is scope for new enterprises of young people, in various fields (creative sector, green economy, modern services), and established companies are willing to give support, if they benefit in some way through learning or participation, and startup plans are mature enough (the ideation phase should be concluded). In Albania, the Protik IT Resource Centre is a first example of fostering innovation and entrepreneurship in the IT sector. Other sectors could follow this example. Scale- up concerns firm size and most likely also geographical scale - internationalization, and demand better insights into appropriate financial markets.

Point three is the principle of open innovation. Simply said: working together to develop and market innovation. In the services economy, the nature of innovation is quite distinct from the industrial economy (see for example Dodgson \& Gann, 2014). Companies are dependent on one another and collaboration between firms is required A clear example is the tourism sector. In a business culture characterized by rather low trust levels (FIAA, 2015; IMF, 2015; Vajjhala \& Vuetic, 2013) collaboration is a challenge. Established firms are interested to learn more about innovation, but are hesitant to share inside information with others. That has to do probably with the domestic competition mind-set, with a small market and with a zero sum way of thinking. Since trust in the government is low, public sector institutions are not likely to be the right vehicle for fostering trust, business institutions would have to work on this.

Finally, the creative sectors must be mentioned, small firms that have their origin in individual creativity, skill and talent and which have a potential for wealth and job creation. Activities that constitute the creative industries include advertising, architecture, arts and crafts, broadcasting, design and fashion, film, games, music, performing arts, publishing and printing, and software and computer services. Creative sectors can help business in various sectors and they also have much to offer for the industry (Müller et al., 2008). In Albania the creative sectors are still linked too much to the realm of arts and not to business and wealth creation. Their potential contribution to enhance customer value is hardly considered, they are not well integrated in business. The creative sectors can easily establish international connections for open innovation and can work for the 
international market. The creative sector can function as a catalyst for innovation and is a rather easy entry point to stimulate innovation since R\&D investments needed in the sector are relatively modest.

\section{Conclusions}

In this article we have shown the results of a literature search on innovation in Albania and we have carried out empirical work. The literature clearly shows that innovation and innovation capabilities in Albania, and other Western Balkan countries too, are limited. International agencies and the Albanian government have made some small steps towards building a national innovation system. After contextualizing innovation in Albania, we have defined two main issues with regards to this approach: - it is questionable whether the underlying innovation policy logic of richer OECD countries will work in countries like Albania; - and it is questionable whether the government can play its perceived role in building up a national innovation system, since the government is not even capable as yet to create a good business climate. The results of our empirical study confirm what literature suggests on limited innovative capacities, and tell us that entrepreneurs do not have much confidence in government.

We came to the conclusion that a pragmatic, business focused orientation towards innovation give more results than working on a national innovation system. Business organizations could play a positive role, while government could better focus on improving legal and institutional conditions that influence the business climate Special attention should be given to fostering open innovation, and to exploring what the contribution of the creative sectors could be to more innovation.

In the field of business development, Albania faces new challenges. After a period of rapid economic development, the economic slow-down since 2008/9 has changed the situation. This slow-down can be seen as a driver for business innovation: businesses may now formulate better strategies and enter international competition. The business context - development of legal and institutional frameworks - needs further improvement from the side of the government. In terms of innovation, a pragmatic and incremental innovation approach rather than building a national innovation system is considered to be an opportune path to follow. And not just for Albania, for neighboring countries in the Western Balkan as well.

\section{References}

Agency for Research Technology and Innovation (AKTI). (2014). 1st National Catalogue of Innovations for Human Development in Albania. Tirana.

Archibugi, D., Denni, M., \& Filippetti, A. (2009). The technological capabilities of nations: The state of the art of synthetic indicators. Technological Forecasting and Social Change, 76, 917-931.

Bahiti, R., \& Shahini, B. (2010). Strengthening Innovation and Technology Policies for SME Development in Albania. Wspótczesna ekonomia, 13(1), 191-205. http://ce.vizja.pl/en/download-pdf/id/149

Cvetanovic, S., Despotović, J., Mladenović, I., \& Jovović, D. (2014) The analysis of innovation in Western Balkan countries in 2012. Economic Research-Ekonomska Istraživanja, 27(1), 830-846 http://dx.doi.org/10.1080/1331677X.2014.974920

Davila, T., Epstein, M. J., \& Shelton, R. (2013). Making innovation work, how to manage it, measure it, and profit from it. Upper Saddle River, NJ: Pearson FT Press.

Dodgson, M., \& Gann, D. M. (2014). Technology and innovation. In M. Dodgson, D. M. Gann \& N. Phillips (Eds.), The Oxford handbook of innovation management (pp. 375-393). Oxford: Oxford University Press.

Feimi, D., \& Kume, V. (2014). Innovation management: types, management and innovation performance in Albania. European Scientific Journal, 10(7), 239-248. Retrieved from http://eujournal.org/files/journals/1/articles/2980/submission/review/2980-8586-1-RV.pdf

Foreign Investors Association of Albania (FIAA). (2015). Business Environment, 2015 Survey. Tirana. Retrieved from http://fiaalbania.al/business-environment-2015-survey

IMF. (2015). The Western Balkans: 15 years of economic transition. Washington, D.C. Retrieved from https://www.imf.org/external/pubs/ft/reo/2015/eur/eng/pdf/erei_sr_030915.pdf

Kozłowski, J. (2015). Innovation indices: The need for positioning them where they properly belong. Scientometrics, 104(3), 609-628. http://dx.doi.org/10.1007/s11192-015-1632-4

Kravtsova, V., \& Radosevic, S. (2011). Are systems of innovation in Eastern Europe efficient? Economic Systems, 36, 109-126. http://dx.doi.org/10.1016/j.ecosys.2011.04.005

Kume, V., \& Xhuka, Z. (2010). Innovation management in the insurance sector in Albania. Journal of 
Entrepreneurship and Innovation, 2, 94-107. Retrieved from http://fbm.uni-ruse.bg/jei/Issue-2010/09-2010-JEI-Vasilika-Kume-Edited-Final-M.pdf

Marinkovic, I., \& Dall, E. (2014). R\&D and innovations in Western Balkans, Moving towards 2020. Vienna. Retrieved from http://wbc-inco.net/object/document/13962/attach/PUBLIKATION_WBCINCO_web.pdf

Mehmeti, V. (2014). Improving the Business Climate of Albania EU Integration as a Surrogate for an Efficient Public Administration and Simplified Legal Framework. Interdisciplinary Journal of Research and Development, $\quad 1(1), \quad 20-25 . \quad$ Retrieved from http://www.uamd.edu.al/new/wp-content/uploads/2015/01/Valbona-Mehmeti-4.pdf

Müller, K., Rammer, C., \& Trüby, J. (2008). The role of creative industries in industrial Innovation. Centre for European Economic Research; Discussion Paper No. 08-109. Retrieved from http://ftp.zew.de/pub/zew-docs/dp/dp08109.pdf.

Nientied, P. (2015). Polis University as a lean startup innovation. International Business Research, 8(5), 19-29. http://dx.doi.org/10.5539/ibr.v8n5p19

OECD. (2015). The innovation imperative contributing to productivity, growth and well-being. Paris: OECD Publishing.

Patterson., F., Kerrin, M., Gatto- Roissard, G., \& Coan, P. (2009). Everyday innovation, How to enhance innovative working in employees and organisations. London, NESTA, EI/43. Retrieved from http://www.nesta.org.uk/publications/everyday-innovation

Prašnikar, J., Memaj, F., Redek, T., \& Voje, D. (2013). The role of corporations in economic development: Albania on its way to internationalisation. Post-Communist Economies, 25(3), 309-406. http://dx.doi.org/10.1080/14631377.2013.813143

Prašnikar, J., Redek, T., \& Memai, F. (2012). Albania: the role of intangible capital in future growt. Ljubljana: Faculty of Economics. Retrieved from http://maksi2.ef.uni-lj.si/zaloznistvoslike/371/Albania_cela.pdf

Redek, T. (2012). The Case of R\&D. In Prašnikar et al., (Eds.), pp. 99-124.

Redek, T., Memaj, F., Prašnikar, J., \& Trobec, T. (2012). Albania, Two decades of economic development at a glance.

Republic of Albania, Council of Ministers. (2009). National strategy of science, technology and innovation 2009-2015. Tirana.

Sloan, B. (2001). Developing the linkage between policy and innovation measurement. Paper presented at the DACST/OECD Seminar on Innovation Measurement in OECD and non-OECD countries. Pretoria, 28-29 March 2001. http://cordis.europa.eu/pub/indicators/docs/ind_wp_bs1.pdf

Švarc, J. (2012). Comparative analysis of the innovation capacities in the WBC with emphasis on joint cooperation needs in the field of innovation. Proceedings of International Conference for Entrepreneurship, Innovation and Regional Development ICEIRD 2012, Sofia Bulgaria. Retrieved from http://wbc-inco.net/object/event/5694/attach/06_svarc_WBC_Innovation_2011-12-01.pdf

Tidd, J., \& Bessant, J. (2013) Managing innovation, integrating technological, market and organizational change. Chichester: Wiley.

United Nations Economic Commission for Europe (UNECE). (2012). Fostering innovative entrepreneurship, challenges and policy options. New York-Geneva: UNECE. Retrieved from http://www.unece.org/fileadmin/DAM/ceci/publications/fie.pdf

Vajjhala, N., \& Vucetic, J. (2013). Key barriers to knowledge sharing in medium-sized enterprises in transition economies. International Journal of Business and Social Science, 4(13), 90-98 Retrieved from http://ijbssnet.com/journals/Vol_4_No_14_November_2013/12.pdf

Vladi, B. (2013). The open innovation model: explaining the factors that hinder its implementation in the Albanian banking system. Paper for CBU Intl. Conference on Integration and Innovation in Science and Education, 7-12. Retrieved from http://ojs.journals.cz/index.php/CBUConference2013/article/download/16/18.

WBC-INCO.NET. (2011). Report on the mapping of the WBC innovation infrastructures Albania. Retrieved from http://aida.gov.al/wp-content/uploads/2012/10/1Albania_Public_Final_v02.pdf

World Bank. (2011). Regional R\&D strategy for innovation in the Western Balkan countries-key issues and 
implications for technical assistance. Washington, D.C.

World Bank. (2013). Western Balkans, regional R\&D strategy for innovation-country paper series Albania. Washington, D.C.

World Economic Forum (WEF). (2014). Enhancing Europe's competitiveness, fostering innovation-driven entrepreneurship in Europe. Geneva. Retrieved from $\mathrm{http}: / / \mathrm{www}$.weforum.org/reports/enhancing-europes-competitiveness-fostering-innovation-driven-entrepren eurship-europe

World Economic Forum (WEF). (2015). The global competitiveness report 2015/2016. Geneva. Retrieved from $\mathrm{http} / / /$ reports.weforum.org/global-competitiveness-report-2015-2016/economies/\#economy=ALB

Xheneti, M., \& Bartlett, W. (2012). Institutional constraints and SME growth in post-communist Albania. Journal of Small Business and Enterprise Development, 19(4), 607-626. http://dx.doi.org/10.1108/14626001211277424

Zavalani, O., Shabani, A., Spahiu, A., \& Dhamo, L. (2015). Innovation, technology transfer and automation systems in Albania. HCTL Open International Journal of Technology Innovations and Research (IJTIR), 14, April. Retrieved from http://ijtir.hctl.org/vol14/IJTIR_Article_201504004.pdf

\section{Copyrights}

Copyright for this article is retained by the author(s), with first publication rights granted to the journal.

This is an open-access article distributed under the terms and conditions of the Creative Commons Attribution license (http://creativecommons.org/licenses/by/3.0/). 